\title{
13
}

\section{Towards a Respectful Repatriation of Stolen Ainu Ancestral Remains}

\author{
Yuji Shimizu (translated by Jeff Gayman)
}

\section{Introduction}

It has been 85 years since Hokkaidō University began desecrating Ainu graves and removing the human remains of our revered ancestors. In 2012, several Ainu descendants decided to take action to achieve the repatriation of their ancestors' remains. Banding together under the slogan, 'Return the Ainu Remains to the Soil of the Ainu Kotan (village)', they brought a suit against Hokkaidō University (see Figure 9).

After a number of hearings, however, it had become plain from the advanced age of the plaintiffs that continuation of the litigation would be extremely difficult. Faced with the agonising decision of whether or not to proceed with the lawsuit, the lawyers for the plaintiffs, together with the citizens' support organisation, the Hokkaidō University Information Research Disclosure Group, eventually agreed to pursue other avenues. As a result, on 25 March 2016 an historic out-of-court settlement was reached between the plaintiffs and Hokkaido University. With this, the repatriation of Ainu ancestral remains achieved its first legal victory. 


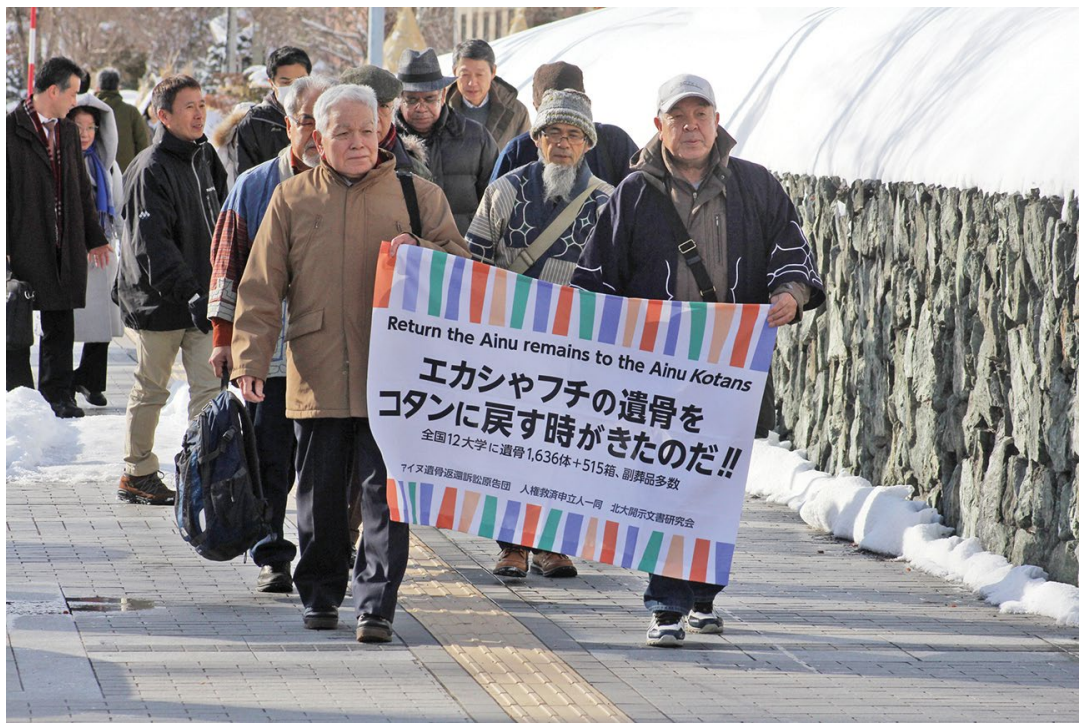

Figure 9. Yuji Shimizu and other members of the Kotan Association in a demonstration demanding the return of ancestral remains.

Source. Photographed by freelance journalist Tsuyoshi Hirata, in front of the Sapporo District Court, 26 January 2018. Used with permission.

As a result of the settlement, the matter arose of who should be the recipient of the ancestral remains. In response, Ainu activists rapidly established the Kotan no Kai (Kotan Association). This association was made up of Ainu hailing from Hokkaidōs Hidaka District, and their task was to serve as the legal recipient organisation for the remains. However, this development in turn brought the members face-to-face with the historically unprecedented task of reinterment of the Ainu remains, which was completely uncharted territory for them. In order for the ancestors to return to the beloved soil of their village, the top priority became to find a suitably proper and dignified way of conducting the reception and reburial ceremonies. The members of the Kotan no Kai were thus faced with the daunting challenge of responding creatively, progressively and with appropriate caution. 


\section{The historical background to the collection of Ainu human remains}

Starting from the latter decades of the nineteenth century, European and North American scientific researchers from the disciplines of Comparative Anthropology and Physical Anthropology collected, weighed and measured thousands of skulls from ethnic groups around the globe. They were seeking to advance comparative research which would verify racial traits such as personality and intellectual ability, and thereby ultimately shed light on 'human evolution'. At this time, scholars' attention came to focus intensely on the Ainu, who, due to their physical resemblance to Caucasians, were considered to be a possible 'Racial Isolate of the Orient'.

Beginning in the mid-Meiji Era (1868-1908), Japanese researchers joined the bandwagon of those searching for human remains. The Japanese, furtively, and at times blatantly, desecrated Ainu graves and robbed the contents for the purpose of collecting skull specimens. From the 1930s onward, Hokkaidō Imperial University was responsible for collecting more than 1,000 Ainu individuals from over 50 locations in Hokkaidō and neighbouring islands. According to a recent official survey by the Japanese Ministry of Education and Culture, researchers from 12 universities throughout the nation of Japan collected and conducted research on the remains of 1,637 Ainu individuals. These remains are currently housed at their universities.

Incidentally, in what was likely a variation on such research, I have memories from childhood of having my skull measured for survey purposes, and my blood drawn for specimens. In this way, in the process of the modernisation of Japan, the Ainu were put into the position of being mere objects of research. I believe that, presently, the discipline of Cultural Anthropology continues to expand the scale of these one-sided survey and research activities.

\section{Approaching Hokkaidō University about initiating talks}

On the morning of 17 February 2012, Ainu Elders Mr O. and Mrs J. visited the Administrative Headquarters of Hokkaidō University. They sought a personal or informal audience with the University President. However, not only were they denied seeing the head of the university, 
but they were further confronted unceremoniously outside the front door by burly security guards who the university had hired to prevent their entrance. Despite the fact that these two elderly Ainu had sent an advance letter requesting an interview, the barring of their entrance by physical force continued for five hours in the midst of biting cold and spitting snow. Ultimately, the two Elders' quest ended in the mere submission of another letter again requesting an interview.

Nonetheless, several more months passed with no response or answer. Ultimately, this meant that two Ainu descendants who had approached Hokkaidō University seeking consultation about the repatriation of their ancestors were met with nothing other than silence and a forceful rejection of their requests.

\section{Litigation towards repatriation}

As a result of this unreasonable treatment, the two Ainu filed suit with the Sapporo District Court against Hokkaidō University for the repatriation of their ancestors. Starting from 2012, approximately 10 hearings were conducted, with no progress being made. Then, as the advanced age of the three plaintiffs was beginning to delay the court proceedings, they agreed, in response to urgings from the court, to shift to out-of-court talks, which continued for another twelve months.

On 25 March 2016, a historic and unprecedented out-of-court agreement to repatriate 12 Ainu individuals to their home community was reached, in opposition to all previous repatriation guidelines set out by either the Japanese State or Hokkaidō University. Until that time, under the 'Household System' prescribed by Japanese civil law, only direct descendants of the deceased had had the right to gain possession of the remains of their ancestors or serve as ritual successors. Indigenous policy guidelines likewise had required that all Ainu applying for repatriation must be direct descendants of the deceased. The Sapporo District Court, in issuing a recommendation that the out-of-court settlement be achieved through repatriation to a group which could, 'serve in the Kotan's place', honoured the Ainu tradition of all members comprising a kotan that qualified as the proper caretakers of the village's ancestors. The organisation born out of this series of events was the Kotan no Kai. 


\section{Toward a dignified repatriation of Ainu ancestral remains}

On 20 December 2015, Kotan no Kai was established as the recipient body for the Ainu ancestral remains. One crucial matter for our group at this juncture was to clarify the original context at stake behind the return of our ancestors. In other words, through discussing the issues and learning about and verifying the historical facts of the process leading up to the return of our forebears, we were able to come to a consensus amongst ourselves that possession in the first place by scholars and researchers of our ancestors' remains was nothing other than 'theft for the sake of gathering specimens'. What follows are the points we mutually agreed should serve as the principles guiding the activities of our group as the receiving organisation for the ancestral remains:

1. We will seek an earnest and ethically motivated apology from Hokkaidō University (the Japanese State) and scholars/researchers.

2. We, as Ainu, will receive the ancestors according to our own will, and will engage in all earnestness according to Ainu custom in ceremonies for the appeasement of their souls.

3. We will proactively disseminate information about our activities both domestically and internationally; the weighty historical significance of the repatriation mandates that this knowledge be shared.

The above are not only mere promises that we made amongst ourselves, but rather a commitment to broadcasting and seeking support for our philosophy both domestically and internationally.

Concretely speaking, we were able to achieve the repatriation of the remains of 12 individuals, which we welcomed back to the village over the course of three days of ceremonies. Day one included Kamuynomi (a prayer ceremony to the Kamuy, Ainu spirits) to honour the return of the ancestors to their home village, after their hurriedly having been transferred over several hours by car from the Hokkaido University Ossuary to the Kineusu Cemetery in Urakawa Town. On day two the ceremony included Kamuynomi to appease the spirits of the ancestors for having suffered detainment for 85 years in an unhospitable environment. On day three we held the reburial (Kamuynomi) ceremony and Icarpa (ancestral remembrance ceremony) to pray that the souls of the ancestors might rest in eternal peace. 


\section{In conclusion}

The reburial of our ancestors' remains finished without undue occurrences. Questions had plagued our minds as to the proper way for Ainu to perform a 'reburial', without causing offence to the spirits of our ancestors. After all, it was the very first time in history that such a task had been performed. We proceeded with enactment of the rituals without ever having received any certain confirmation that what we planned to do was in no way offensive to our ancestors. Nonetheless, our efforts were constantly driven by a progressive, creative esprit, and the genius of innovation. And we made a point of always maintaining a calm and reverent attitude and proceeding with sanctity, despite our anxiety. Today, I know from the peace of my dreams since the reburial that we succeeded in faithfully carrying out our duty and achieving a noteworthy reburial of the ancestors' remains.

However, the majority of the 1,637 ancestors still remain housed at Hokkaidō University and 11 other universities. Already the process of reconciliation is further clouded by a project designed to transfer Ainu ancestral remains from these universities to a shared charnel facility to be constructed inside of the National AINU Museum and Park scheduled to open in Shiraoi in 2020. This agenda is political, which must be halted at all costs (see Figure 10).

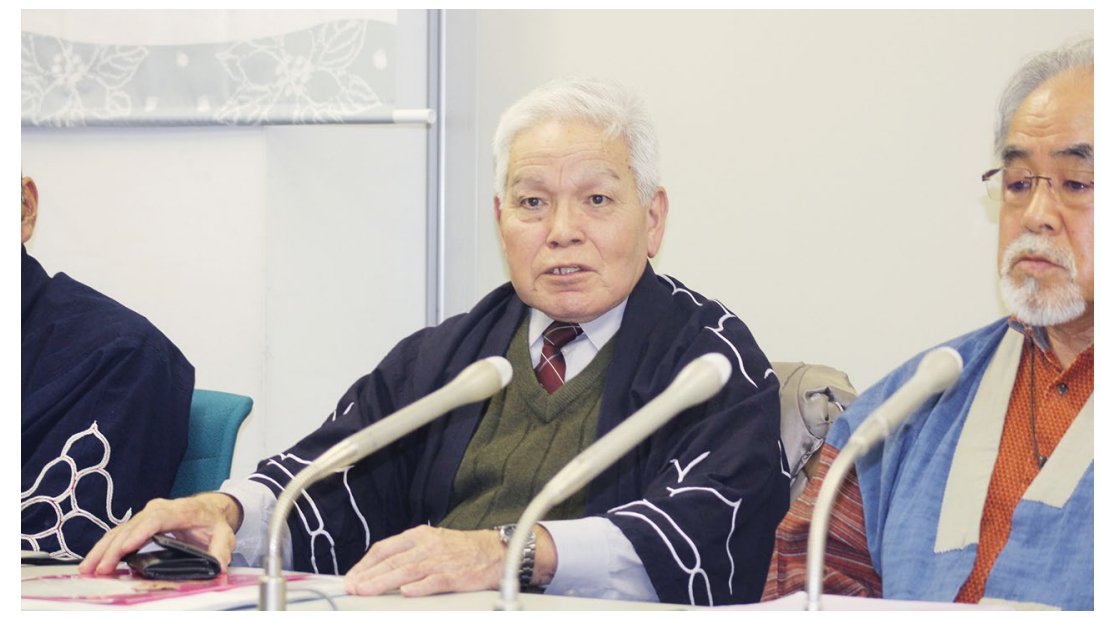

Figure 10. Yuji Shimizu at a press conference in the Sapporo Bar Association Hall.

Source. Photographed by freelance journalist Tsuyoshi Hirata, 26 January 2018. Used with permission. 
This text is taken from Indigenous Efflorescence: Beyond Revitalisation in Sapmi and Ainu Mosir, edited by Gerald Roche, Hiroshi Maruyama and Åsa Virdi Kroik, published 2018 by ANU Press, The Australian National University, Canberra, Australia.

doi.org/10.22459/IE.2018.13 